\title{
原著：
}

\section{当院における予定日超過のため 分婏誘発した症例の分婏転㷌の検討}

\author{
武永智*.秋葉 靖 雄* - 田口圭 祐* \\ 水戸裕二朗*・吉 田 卓 功*
}

本邦では妊娠41週の妊婦の管理について一定の指針が決まっておらず，各施設に管理方 針が委ねられている。当院では妊娠41週の妊婦に対して症例によって分娩誘発を行なって いるが，分娩転帰として緊急帝王切開に至る症例，分娩後に弛緩出血で治療を要する症例 や児がNICUに入室する症例を経験する。そこで，どの症例にこのような事象が起こり やすいかを後方視的に検討した。

2013年 1 月から2015年12月までの 3 年間に当院で分婏した 3,492 例のうち，妊娠41週に 分娩となった 382 例を対象とした。経産婦の緊急帝王切開率が $1 \%$ であったのに対して, 初産婦は $21 \%$ と高值であったため，初産婦に焦点を当てて検討した。

382例の中で, 初産婦は258例あり, 妊娠41週まで未破水，未陣発のために分娩誘発を行 なった初産婦は122例（以下，誘発群）と妊娠41週になり陣痛発来もしくは前期破水した 初産婦は136例（以下, 非誘発群）であった。誘発群は非誘発群と比較し, 高年妊婦や妊 娠中に体重増加した妊婦が多く，緊急帝王切開となるリスクも高かった。一方で，児が NICU に入室する割合に有意差は認められなかった。誘発群に絞った検討では, 誘発日 数を要した症例や高年妊娠になるほど緊急帝王切開率が高かった。

妊娠年齢の高齢化に伴い, 妊娠中の体重増加のリスクに関して啓蒙していく必要があ る。

(1)分娩誘発 (2)予定日超過

\section{諸言}

妊娠41週以降の妊婦の取り扱いに関して，分 婏誘発の方が待機分婏よりも母児予後が良いと する複数のランダム化比較試験やメ夕解析が報 告されている。これらはいずれも児死亡率，児 罹患率および帝王切開率の減少傾向を認めてい る ${ }^{1 \sim 4)}$ 。一方で妊娠41週台に限定したランダム 化比較試験とメ夕解析は存在せず，完全に一致

* =230-0012 神奈川県横浜市鶴見区下末吉3-6-1 済生会横浜市東部病院産婦人科 （受付：2019年 2 月18日）
した誘発分娩の優位性は示されていない。英国 では，妊娠41週は積極的に分娩誘発すべきとの ガイドラインはあるが，わが国では，妊娠41週 の妊婦に分娩誘発を行なうか, 分娩待機とする かは，各施設に管理方針が委ねられているのが 現状である ${ }^{1,5)}$ 。

当院では, 妊娠41週の予定日超過症例に対し て過期産子防の目的もあり症例によって分娩誘 発を行なっている。しかし, 自然分婏を希望し ている，薬剤使用によって陣痛が過度に強くな る等, 分婏誘発を行なうことに抵抗を感じる妊 婦が多いという側面もある。そこで当院におけ る過去 3 年間の妊娠 41 週の分娩転帰を後方視的 
に解析し，誘発群と非誘発群に打けるリスク因 子と有用性について検討した。

\section{方法}

2013年 1 月 1 日から 2015 年12月31日までの 3 年間に当院で分娩した 3,492 例のうち，妊娠41 週に分娩となった 382 例を対象とした。このう ち, 経産婦の緊急帝王切開率が 1 \%であったの に対して, 初産婦の緊急帝王切開率は $21 \%$ と高 值であったため, 初産婦に焦点を当てて検討し た（表 1)。382例の中で, 初産婦は258例あり， 妊娠41週まで陣痛が発来せず頸管熟化が不良な ために分婏誘発した例や過期産予防のために分 婏誘発を行なった初産婦122例（以下，誘発群） と妊娠 41 週になり陣痛発来した例, 前期破水し た例，および分娩誘発予定であったがその前に 陣痛発来, 前期破水し入院した初産婦136例 (以 下, 非誘発群）にわけて検討した。尚, 誘発群 には妊娠41週に分娩誘発を行ない，妊娠42週に 分婏となった症例も含めており，妊娠 42 週に分 婏となった症例は全例誘発群の症例であった。

検討にあたり，単胎であること，予定日が CRL14mm-41mm の時期に決定されているこ と, 妊娠高血圧症候群等の母体合併症がないこ と, 子宮内胎児発育不全がないこと, 予定帝王 切開でないことを前提とした。

当院は妊娠41週以降になると過期産予防のた めに分婏誘発を考慮し，母児の状態を鑑みなが ら担当医の判断で誘発時期を決定し, 頸管熟化 不良例には器械的頸管拡張としてミニメトロ ${ }^{\circledR}$ $40 \mathrm{ml}$ を挿入し, 留置は原則 1 日間のみとして
いる。陣痛促進剂は, 原則的にはオキシトシン としているが，担当医の判断で症例によっては PGF $2 a$ やPGE 2 を使用している。点滴薬剤 の投与方法は産婦人科診療ガイドライン産科編 2017に準じて使用している。薬剤使用は 3 日間 連続を最長とし， 1 日薬剤を使用しない期間を 設けてから再度薬剤使用としており，分娩に至 らない場合は最大で合計 5 日間の薬剤使用で帝 王切開としている。また, 非誘発群を陣痛発来 した例，前期破水した例，および分娩誘発予定 であったがその前に陣痛発来, 前期破水した例 としたが, 微弱陣痛, 破水後 24 時間経過しても 分娩に至らない例には陣痛促進剤としてオキシ トシンを使用している。頸管拡張は非誘発群に は全例行なっていない。

検討対象は, 第 1 に誘発群と非誘発群の分娩 転帰，母体情報の比較とし，第 2 に誘発群の分 娩転帰が帝王切開となった症例（以下，帝王切 開群）と経腟分婏となった症例 (以下, 経腟群) とした。検討項目は両群間の年齢, 非妊娠時 · 分婏時 BMI，非妊娠時から分婏時までの体重 増加量, 5 分後 Apgar score, 出生時体重, 児 の NICU 入室率, 緊急帝王切開率, 経腟分娩 時に $1,000 \mathrm{ml}$ 以上の弛緩出血が生じた率とし た。

デー夕は平均値（範囲）もしくは頻度（\%） で示し, 統計的検討は Student-t 検定を用い, $\mathrm{p}<0.05$ を有意差ありと判定した。

\section{倫 理 的 配 慮}

今回の論文の症例に関して当院の倫理委員会

表 1. 妊娠41週 初産婦と経産婦の分婏転帰

\begin{tabular}{|c|c|c|c|c|}
\hline & 全体（ $\mathrm{n}=382 ）$ & $\begin{array}{l}\text { 初産婦 } \\
(\mathrm{n}=258)\end{array}$ & $\begin{array}{c}\text { 経産婦 } \\
(\mathrm{n}=124)\end{array}$ & $\begin{array}{c}\text { 誘発群と非誘発群の } \\
\text { 比較 }\end{array}$ \\
\hline 経腟分婏数 & 326 & $203(78.7 \%)$ & $123(99.2 \%)$ & $\mathrm{p}<0.001$ \\
\hline 帝王切開数 & $56(14.7 \%)$ & $55(21.3 \%)$ & $1 \quad(0.8 \%)$ & $\mathrm{p}<0.001$ \\
\hline $\begin{array}{c}\text { 心音異常による } \\
\text { 帝王切開数 }\end{array}$ & $29 \quad(7.6 \%$ & $28(10.9 \%)$ & $1 \quad(0.8 \%)$ & $\mathrm{p}<0.001$ \\
\hline 5 分後 Apgar & $9.1 \quad \pm 0$. & $9.1 \quad( \pm 1$ & $9.2 \quad( \pm$ & $p=0.882$ \\
\hline NICU 入室数 & $33 \quad(8.6 \%$ & $27(10.5 \%)$ & $6 \quad(4.8$ & $p=0.007$ \\
\hline 弛緩出血数 & $59(15.4 \%)$ & $40(15.5 \%)$ & $19(15.3 \%)$ & $p=0.792$ \\
\hline
\end{tabular}

表記：平均值（土標準偏差）または（\%） 
の承認（承認番号2018088）を得ている。

\section{結果}

当院において 2013 年 1 月から 2015年12月まで の 3 年間に妊娠41週で分娩した初産婦は258例 であった。このうち, 経腟分婏は203例 $(78.7 \%)$, 緊急帝王切開分娩は55例（21.3\%）であった。 児が NICUに入室したのは 27 例 $(10.5 \%)$ ，経 腟分婏時に $1,000 \mathrm{ml}$ 以上の弛緩出血が生じた症 例は40例（15.5\%）であった（表 $2 ） 。$

この258例の初産婦を誘発群122例と非誘発群 136例に分類し，各群の分娩転帰を表 2 に，母 体情報を表 3 にそれぞれ示した。

誘発群の帝王切開率は27.9\% (34件) であり, 非誘発群 $15.4 \%$ （21件）と比較して有意に増加 していた $(p=0.014)$ 。有意差は認めないが誘 発群の方が NICU 入室率が低い傾向を認めた。
また，年齢が上昇するほど誘発群となる確率が 有意に上昇しており $(p=0.041)$, 40歳以上の 高齢になればその傾向がより有意となった（p $=0.002)$ 。分婏時週数, 非妊娠時 BMI は両群 間で有意差は認めなかったが，妊娠中の体重増 加量に関しては誘発群が有意に増加していた $(\mathrm{p}=0.031)$ 。児の体重に関しては両群に差は認 めなかった。

次に, 分婏誘発の分婏転帰として, 帝王切開 群と経腟分娩群を比較し母体情報を表 4 に示し た。帝王切開群は経腟分婏に比較して年齢が有 意に高く $(p=0.003)$, 高年初産も多い結果と なった（p=0.029）。また，高年初産は約 4 割 が帝王切開となっており，分婏転帰不良であっ た。入院時の Bishop score は両群で明らかな 差は認めなかったが, 分娩所要日数は帝王切開 群が有意に延長していた（p<0.001）。妊娠前・

表 2. 初産婦における誘発群と非誘発群の分娩転帰

\begin{tabular}{|c|c|c|c|c|}
\hline & $\begin{array}{c}\text { 初産婦全体 } \\
(\mathrm{n}=258)\end{array}$ & $\begin{array}{c}\text { 誘発群 } \\
(\mathrm{n}=122)\end{array}$ & $\begin{array}{l}\text { 非誘発群 } \\
(\mathrm{n}=136)\end{array}$ & $\begin{array}{c}\text { 誘発群と非誘発群の } \\
\text { 比較 }\end{array}$ \\
\hline 経臸分娩数 & $203(78.7 \%)$ & $88(72.1 \%)$ & $115(84.6 \%)$ & $\mathrm{p}=0.014$ \\
\hline 帝王切開数 & $55(21.3 \%)$ & $34(27.9 \%)$ & $21(15.4 \%)$ & $p=0.014$ \\
\hline $\begin{array}{c}\text { 心音異常による } \\
\text { 帝王切開数 }\end{array}$ & $28(10.9 \%)$ & $17(13.9$ & $3.1 \%)$ & $p=0.133$ \\
\hline 5 分後 Apgar & $9.1 \quad( \pm 1.0)$ & $9.1 \quad( \pm 1.0)$ & $9.1 \quad( \pm 1.0)$ & $\mathrm{p}=0.912$ \\
\hline NICU 入室数 & $27(10.5 \%)$ & $9 \quad(7.4 \%)$ & $18(13.2 \%)$ & $p=0.126$ \\
\hline 弛緩出血数 & $40(15.5 \%)$ & $21(17.2 \%)$ & $19(14.0 \%)$ & $\mathrm{p}=0.474$ \\
\hline
\end{tabular}

表記：平均值（土標準偏差）または（\%）

表 3. 初産婦における誘発群と非誘発群の母体情報

\begin{tabular}{|c|c|c|c|c|c|c|c|}
\hline & \multicolumn{2}{|c|}{$\begin{array}{c}\text { 初産婦全体 } \\
(\mathrm{n}=258)\end{array}$} & \multicolumn{2}{|c|}{$\begin{array}{l}\text { 誘発群 } \\
(\mathrm{n}=122)\end{array}$} & \multicolumn{2}{|c|}{$\begin{array}{l}\text { 非誘発群 } \\
(\mathrm{n}=136)\end{array}$} & $\begin{array}{c}\text { 誘発群と非誘発群の } \\
\text { 比較 }\end{array}$ \\
\hline 妊娠週数 & 41週2日 & $( \pm 1.9)$ & 41週3日 & $( \pm 1.7)$ & 41週2日 & $( \pm 1.7)$ & $\mathrm{p}<0.001$ \\
\hline 年齢（歳） & 32.6 & $( \pm 5.2)$ & 33.3 & $( \pm 5.3)$ & 32.0 & $( \pm 5.0)$ & $\mathrm{p}=0.041$ \\
\hline 高年初産数 & 94 & $(36.4 \%)$ & 51 & $(41.8 \%)$ & 43 & $(31.6 \%)$ & $\mathrm{p}=0.093$ \\
\hline 40歳以上初産婦数 & 23 & $(8.9 \%)$ & 18 & (14.8\%) & 5 & $(3.7 \%)$ & $\mathrm{p}=0.002$ \\
\hline 身長（cm） & 159 & $( \pm 5.5)$ & 159.4 & $( \pm 5.3)$ & 158.6 & $( \pm 5.7)$ & $\mathrm{p}=0.203$ \\
\hline 体重（kg） & 55.6 & $( \pm 10.1)$ & 56.2 & $( \pm 9.9)$ & 55.0 & $( \pm 10.2)$ & $p=0.378$ \\
\hline 非妊娠時 BMI & 22.0 & $( \pm 3.6)$ & 22.1 & $( \pm 3.7)$ & 21.8 & $( \pm 3.5)$ & $\mathrm{p}=0.601$ \\
\hline 体重増加（kg） & 11.3 & $( \pm 3.8)$ & 11.8 & $( \pm 3.7)$ & 10.8 & $( \pm 3.7)$ & $\mathrm{p}=0.031$ \\
\hline 分婏時 BMI & 26.5 & $( \pm 3.8)$ & 26.8 & $( \pm 3.9)$ & 26.2 & $( \pm 3.6)$ & $\mathrm{p}=0.213$ \\
\hline 児体重（g） & 3,254 & $( \pm 360)$ & 3,281 & $( \pm 347)$ & 3,230 & $( \pm 370)$ & $\mathrm{p}=0.255$ \\
\hline
\end{tabular}

表記：平均值（土標準偏差）または（\%) 
表 4. 初産婦における誘発群の中で帝王切開群と経腟分娩群の母体情報

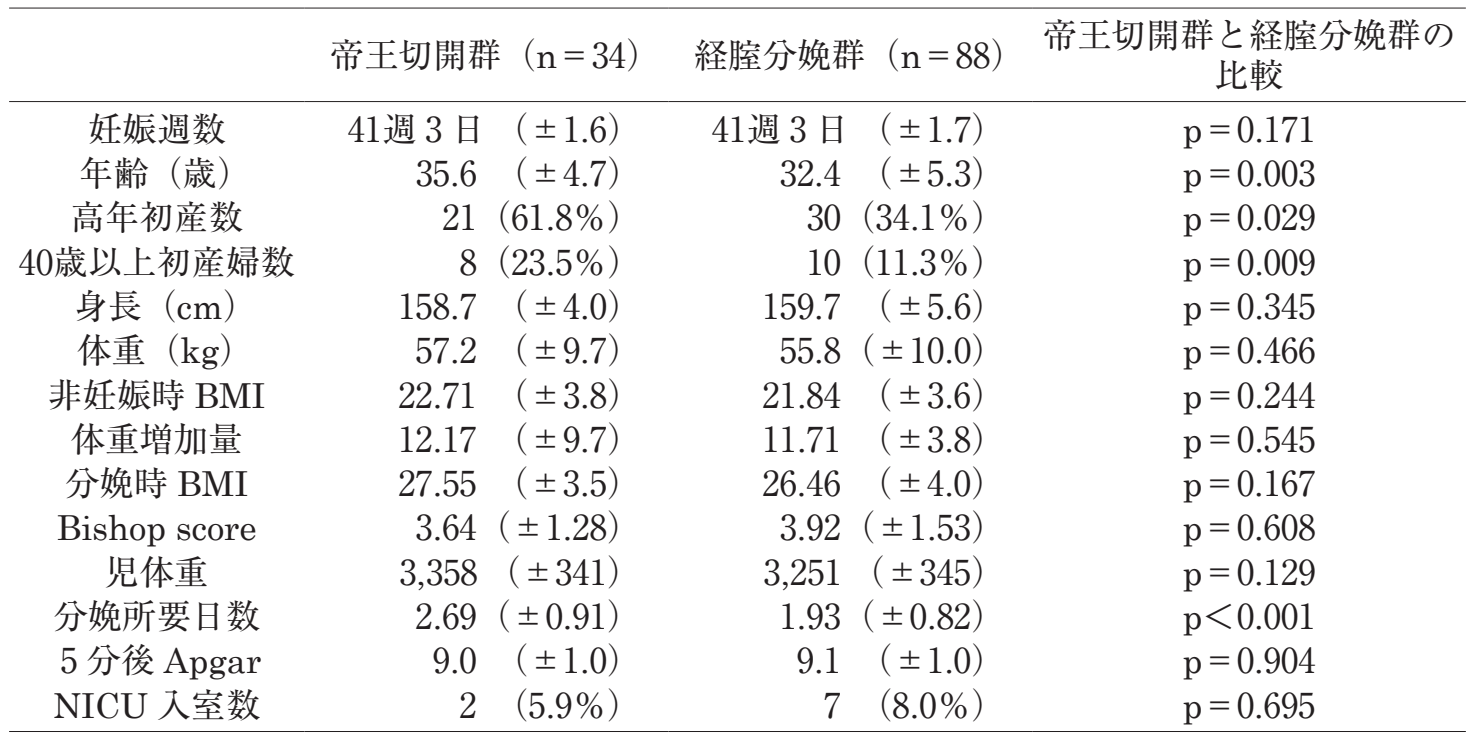

表記：平均値（土標準偏差）または（\%)

分娩時 BMI，妊娠中の体重増加量に有意差は 認めなかったが，帝王切開群の方がいずれも多 い傾向であった。5 分後 Apgar score 值, NICU 入室数は両群間に有意差は認めなかった。

\section{考察}

当院は妊娠41週になった妊婦の中で症例に よって分娩誘発を行なっているが，初産婦であ ることが分娩転帰に大きな影響を及ぼすことが わかり，初産婦に関して検討した。検討では高 齢であることや，妊娠中の体重増加量が多い と，分娩誘発となりやすいことがあらためて明 らかとなった。また，分娩誘発を行なった中で 高齢であることと，分婏所要日数の延長がある と帝王切開率が有意に高く，いかに分婏誘発の 日数を短縮するかが重要であると示唆された。 今回の検討から，初産婦の分娩誘発には年歯, 体重増加の関係性が示唆され, 今後も高年初産 の増加に伴い分娩誘発の増加が予想され，帝王 切開率の上昇が問題となっていくと考えられ る。

加齢は, 結合組織に硬化が起こり筋肉組織の 進展不良による軟産道強勒や子宮頸管熟化不全 となりやすいと考えられている6 筋の反応の低下やオキシトシンやプロスタグラ
ンジンの感受性の低下も指摘されている7)。こ のため妊娠41週となっても陣痛が発来せず分婏 誘発となった妊婦が多くなったと推察できる。 一方で，加齢とともに軟産道強勒とはならず, 娩出力も変化しないとの報告もある ${ }^{8)}$ 。しか し，加齢とともに筋肉全体量としては衰えるの で，たとえ婏出力の瞬発性は保たれていても， 持続性という点で劣ってくることは考慮すべき であろう ${ }^{8)}$ 。そのため，遷延分娩になった場合 は，婏出力低下を招き分婏所要日数の延長を認 めやすいと考えられ，分婏停止や，览頭の長時 間の圧迫による心音異常による緊急帝王切開が 生じると考えられる。また，分婏の 3 要素とし て娩出力, 産道, 娩出物はよく知られていると ころであるが，第 4 の要素として精神状態の存 在が挙げられている9)。不安, 恐怖心が強い人 ほど分婏所要時間が長いという研究もある10)。 直田らは, 高年初産妊婦は妊娠した際に最も気 になった事として自分の年齢，次に自分の身体 の心配であったと報告している11)。そのため, 高年初産は妊娠・分娩への不安を増強させてい ると考えられる。実際，高年初産では，分娩に より不安を感じているという状況も臨床の現場 で頻回に遭遇する。そのため，分娩誘発に当 たっては妊婦の恐怖心をいかに取り除いていく 
かも今後の課題となると考えられる。

体重増加は，軟産道への脂肪沈着による産道 の狭小化が軟産道強勒や子宮頸管熟化不全とな りやすいといわれている ${ }^{12)}$ 。骨盤内の脂肪沈着 を定量的に評価したWischnikの研究では，学 童期の体格指数に用いられるローレル指数に相 関して骨盤内全体，とりわけ骨盤入口部への脂 肪沈着を認めていることが報告されている ${ }^{13)}$ 。 したがって，母体肥満や体重増加過多は，児頭 の小骨盤への陥入を阻害している可能性が考え られる。

また，今回の検討では分娩所要日数の延長が 帝王切開のリスクとなったが，入院時の Bishop score によっては分婏転帰に有意差は 認めなかった。海外の報告では頸管熟化不良例 でも分娩誘発は帝王切開率を有意に下げ，児の 罹病率は低い傾向にあるとの報告があり，当院 の結果は頸管熟化不良であることが帝王切開の 原因とならないことを支持する結果となっ た2,14,15)。一方で，頸管熟化した妊婦は分娩誘発 による分婏誘発の成績が良好であることは知ら れているところである。そのため分娩誘発にな る妊婦に対して予め頸管熟化を促すことが重要 であると考えられる。海外ではPGE 2 経腟ゲ ル剂を使用し頸管熟化を行なうことを標準治療 としているが本邦では使用できず，方針が限ら れた中で如何にして頸管熟化を図っていくかが 今後の課題といえる。また，頸管熟化は頸管の コラーゲン線維の分解に加えヒアルロン酸の急 激な増加が起こり，分娩時には血中のヒアルロ ン酸濃度が増え，分娩第 1 期には低分子ヒアル ロン酸が著明に増えるといわれている16)。ウサ ギではヒアルロン酸腟坐薬の使用で有意な頸管 熟化を認め，妊婦に関しても症例数は少ないが ヒアルロン酸腟坐薬を使用した場合はBishop score，分婏所要時間が有意に短縮したとの報 告もあり，新たな頸管熟化の方法として今後の 研究に期待したい16 18)。

今回の検討では，当院の分娩誘発では児の NICU 入室率は分娩誘発の方が低い可能性が あるという利点は認めたが，帝王切開率はむし ろ上昇させる結果も認めており絶対的に分娩誘
発の有用性を認める結果ではなかった。

今回の検討は，同一施設における一定期間の 症例蓄積の中での検討である。このため施設間 の分娩方針の違いや年代推移の変化などの患者 背景の違いに影響を受けない点が特徴となって いるが，NICU 入室症例が少ない等の問題もあ る。妊娠41週の分娩誘発群, 非誘発群の分娩転 帰について今後もデータの蓄積, 検討が必要と 考えられた。

結論

当院の妊娠41週の管理としては, 高年初産や 体重増加量が多い妊婦は分娩誘発のハイリスク 群であることと，分娩誘発は帝王切開のリスク の上昇はあるが，児の予後改善の可能性が示唆 されていることを理解して，妊婦に対しては妊 婦健診の段階で体重指導を的確に行なっていく ことが肝要であると考えられる。

昨今の社会背景からも今後も初産年齢の上昇 は予想されるので，我々が介入できることとし て体重増加に関してのリスクをより啓蒙してい く必要があると考えられる。

\section{著者の COI 開示}

本論文発表内容に関連して特に申告なし。

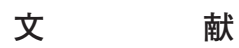

1 ) Inducing labour[CG70]. London: National Institute for Health and Care Excellence (NICE). 2008; https://www.nice.org.uk/（2019.3.12アクセ ス)

2 ) Sanchez-Ramos L, Olivier F, Delke I, et al. Labor induction versus expectant management for post-term pregnancies: a systematic review with meta-analysis. Obstet Gynecol. 2003 ; 101(6) : 1312-1318.

3 ) Gulmezoglu AM, Crowther CA, Middleton P, et al. Induction of labour for improving birth outcomes for women at or beyond term. Cochran Database Syst Rev. 2012 ; 6 : CDOO4945.

4) Caughey AB, Sundaram V, Kaimal AJ, et al. Systematic review: elective induction of labor versus expectant management of pregnancy. Ann Intern Med. 2009 ; 151(4) : 252-263.

5 ）日本産科婦人科学会/日本産婦人科医会. 産婦人 科診療ガイドライン一産科編2017。東京：日本産 
科婦人科学会事務局, $2017 ; 274-277$.

6 ）徳永修一, 池八上 克. 母体年齢と難産. 産と婦 $2003 ; 7: 860-863$.

7 ）笠井靖代, 尾崎倫子, 山田 学, 他. 年齢因子は 分婏に影響するか. 周産期新生览誌 $2012 ； 48$ ： 585-594.

8 ) Ehrenthal DB, Jiang X, Strobino DM. Labor induction and the risk of a cesarean delivery among nulliparous women at term. Obstet Gynecol. 2010 ; 116(1) : 35-42.

9 ）今井公俊. 高齢初産は難産か? 周産期医 $2014 ; 44 ： 129-132$.

10) Adams SS, Eberhard-Gran M, Eskild A. Fear of childbirth and duration of labour: a study of 2206 women with intended vaginal delivery. BJOG $2012 ; 119(10)$ : 1238-1246.

11）直田幸代, 宮田久枝, 岡部惠子. 高齢初産婦の分 婏・妊娠に関する認識 滋賀県下の調査を通して。 母性衛生 2001；42(2)：316-323.

12）高木耕一郎, 村岡光恵. 肥満妊婦と難産. 産と婦 $2003 ; 7: 865-869$.

13) Wischnik A, Lehmann KJ, Ziegler M, et al. Does the "fatty pelvis" exist? Quantitative computer tomography studies. Z Geburtshilfe Perinatol. 1992 ; 196(6) : 247-252.

14) Hannah ME, Hannah WJ, Hellmann J, et al. Induction of labor as compared with serial antenatal monitoring in post-term pregnancy. A randomized controlled trial. The Canadian Multicenter Post-term Pregnancy Trial Group. N Engl J Med. 1992 ; 326(5) : 1587-1592.

15) Caughey AB, Nicholson JM, Cheng YW, et al. Induction of labor and cesarean delivery by gestational age. Am J Obstet Gynecol. 2006 ; 195(3) : 700-705.

16）小川正樹. 科学的な視点から分婏の生理と病理 を探る。頸管熟化の生理と病理. 日産婦会誌 $2011 ; 63(12): 238-243$.

17) Uchiyama T, Matsumoto T, Suzuki Y, et al. Endogenous hyaluronan: a cytokine-like factor present in rabbit uterine cervix during pregnancy. Biol Pharm Bull. 2004 ; 27(12) : 19071912.

18）杉村 基, 福田有佳, 竹内康高, 他. 子宮頸管熟 化制御機構からみた早産の予防。日産婦会誌 2005；57(10)：1581-1590. 


\title{
Induction of Labor and Outcomes of Late-Term Pregnancy in Our Hospital
}

\author{
Tomo TAKENAGA*, Yasuo AKIBA*, Keisuke TAGUCHI*, \\ Yujiro MITO* and Takanori YOSHIDA*
}

In Japan, there are no predetermined guidelines on the management of pregnant women at 41 weeks of pregnancy. In our hospital, pregnant women at 41 weeks of pregnancy are candidates for induction, but induction may result in emergency caesarean section, atonic bleeding postpartum hemorrhage, and neonatal emergencies with admission to the Neonatal Intensive Care Unit (NICU). Therefore, we conducted a retrospective investigation to determine which cases are likely to end in such events. Our hospital recorded a total of 3,492 deliveries during the period 2013-2015. Of these, 382 pregnancies were delivered at 41 weeks. We compared the labor induction group and the spontaneous delivery group. The rate of emergency caesarean section for multiparas was $1 \%$ and was as high as $21 \%$ for primiparas, so we focused on primiparas in this study. The 258 primiparas from among all 382 cases were divided into the induction group $(\mathrm{n}=122)$ and the spontaneous group $(\mathrm{n}=136)$. Compared with the spontaneous group, the induction group had older primiparas, more body weight gain during pregnancy, and a high risk of emergency caesarean section. There was no significant difference in the proportion of neonates admitted to the NICU. In the analysis focused on the induction group, the rate of emergency cesarean section increased as the number of cases requiring induction and the number of elderly primiparas increased. With the recent increasing age of primiparas, it is necessary to educate women on the risks of weight gain during pregnancy.

*Dept. of Obstetrics and Gynecology, Saiseikai Yokohama-Shi Tobu Hospital, Kanagawa, Japan 